\title{
EFFECTS OF PYROLYSIS TEMPERATURE, RESIDENCE TIME ON THE REACTIVITY OF CLEAN COALS PRODUCED FROM POOR QUALITY COALS
}

\author{
G. SKODRAS ${ }^{1,2,3, *}$ \\ P. NATAS ${ }^{3}$ \\ P. BASINAS ${ }^{3}$ \\ G.P. SAKELLAROPOULOS ${ }^{2,3}$
}

\author{
${ }^{1}$ Institute for Solid Fuels Technology and Applications \\ Ptolemais, Greece \\ ${ }^{2}$ Laboratory of Solid Fuels and Environment \\ Chemical Process Engineering Research Institute \\ ${ }^{3}$ Chemical Process Engineering Lab. \\ Aristotle University of Thessaloniki \\ Thessaloniki, Greece
}

Received: 30/5/2005

Accepted: 15/2/2006

*to whom all correspondence should be addressed: e-mail: skodras@vergina.eng.auth.gr

\begin{abstract}
Combustion of poor quality coals is used today worldwide for energy production. The removal of polluting compounds, i.e. $\mathrm{S}, \mathrm{N}, \mathrm{Hg}$ and $\mathrm{Cl}$ from them prior to combustion is important not only for improving the coal quality, but also for meeting the strict environmental standards. Thus, a preventive fuels pre-treatment technique, based on low temperature carbonisation, has been developed that aims to convert 'dirty' fuels to cleaner ones. This study looks at the effect of pyrolysis temperature and residence time on the reactivity of clean coals produced by poor quality coals. Pyrolysis tests of three poor quality coals (Ptolemais, Bulgarian and Australian) were performed in a lab-scale fixed bed reactor, under helium atmosphere and ambient pressure. Ptolemais lignite is the main fuel for electricity production in Greece. The effects of carbonisation temperature $\left(200-900^{\circ} \mathrm{C}\right)$ and residence time $(5-120 \mathrm{~min})$ on the properties of the obtained chars were investigated. Special attention was paid to the polluting compounds ( $\mathrm{S}, \mathrm{N}, \mathrm{Hg}, \mathrm{Cl}$ ) removal. The reactivity under combustion conditions of the Ptolemais chars produced was also investigated. It was observed that low temperature carbonisation could contribute to clean coal production by effectively removing the major part of the existing polluting compounds in the coals. Thus, depending on coal type, nitrogen, mercury and chlorine conversion continuously increase with temperature, while sulphur removal seems to reach a plateau above $500-600^{\circ} \mathrm{C}$. Furthermore, the prolongation of carbonisation time above 20 min does not affect the elemental conversion of the pollutants. Therefore, carbonisation at $500-600^{\circ} \mathrm{C}$ for $\sim 20$ min could be considered sufficient for clean coal production from poor quality coals. The reactivity of the prepared clean coals was evaluated by performing non-isothermal combustion tests in a TA Q600 thermobalance at ambient pressure and $20^{\circ} \mathrm{C} \mathrm{min}{ }^{-1}$ heating rate. At increased pyrolysis temperatures higher initial combustion temperatures were observed, due to the volatile reduction in char production stage. The latter results to lower total conversions.
\end{abstract}

KEYWORDS: coal, carbonisation, clean coal, pollutants removal, reactivity.

\section{INTRODUCTION}

There are abundant reserves of low-rank coals but the combustion of these coals produces large levels of air pollution. The control of pollutants such as sulphur dioxide and nitrogen oxides will require new technologies to be developed to meet stringent environmental regulations, before these low-rank coals can be used as energy sources. Pyrolysis is an important intermediate stage in coal combustion and gasification and also a simple and an effective method for a clean conversion of coal. Under mild pyrolysis condition below $550^{\circ} \mathrm{C}$, 
the pyretic sulfur in coal released mainly in the form of $\mathrm{H}_{2} \mathrm{~S}$. During pyrolysis, the nitrogen in fuel is released as $\mathrm{HCN}, \mathrm{NH}_{3}$, tar- $\mathrm{N}$, etc. Some nitrogen is left in the char. [1] Mercury is present in coal at varying $\mathrm{ng} / \mathrm{g}$ levels and is considered to pose a significant environmental health risk from coal combustion. Elemental mercury has a low boiling point $\left(356^{\circ} \mathrm{C}\right)$ and has been shown to be released from coals at the lower temperatures indicative of mild pyrolysis. [2] The chlorine content of the coal can cause many environmental problems during combustion. The removal of chlorine depends both on the nature of coal and on the nature of chlorine in the coal. Char reactivity has an important effect on the degree of carbon burnout, which is of major consequence from an environmental and economical point of view. [3] Reactivity is defined as the rate at which coal reacts in an oxidizing atmosphere, subsequent to devolatilization. Rank of coal exerts a major constraint on char reactivity, with low rank chars being typically more reactive than those prepared from high rank coals [4].

The aim of this work was to determine the effects of pyrolysis temperature and residence time on the reactivity of clean coals, which were came from poor quality coals by removing polluting elements (i.e. S, N, $\mathrm{Hg}$ and $\mathrm{Cl}$ ) from them.

\section{EXPERIMENTAL}

Greek lignite from Ptolemais seam, Bulgarian lignite from Elhovo and Australian coal were used in this work. Prior to use, samples were dried at $105^{\circ} \mathrm{C}$ in a $\mathrm{N}_{2}$ atmosphere for $24 \mathrm{~h}$, and the desired granulometry $(150-250 \mu \mathrm{m})$ was obtained by grinding and sieving. Proximate and ultimate analysis of the raw samples are given in Table 1 , along with their mercury and chlorine content.

Table 1. Proximate and ultimate analysis of the raw samples

\begin{tabular}{|c|c|c|c|c|c|c|c|c|c|c|}
\hline \multirow{2}{*}{ Samples } & \multicolumn{4}{|c|}{ Proximate analysis (wt\% dry basis) } & \multicolumn{4}{|c|}{ Ultimate analysis (wt\% db) } & \multirow{2}{*}{$\begin{array}{c}\mathrm{Cl} \\
\left(\mu \mathrm{g} \mathrm{g}^{-1}\right)\end{array}$} & \multirow{2}{*}{$\begin{array}{c}\mathrm{Hg} \\
\left(\mu \mathrm{g} \mathrm{g}^{-1}\right)\end{array}$} \\
\hline & Moisture & V.M. $^{a}$ & F.C. & Ash & C & $\mathrm{H}$ & $\mathrm{N}$ & $\mathrm{S}$ & & \\
\hline Ptolemais & 56.82 & 44.84 & 35.17 & 19.99 & 48.55 & 4.17 & 1.48 & 0.72 & 129.2 & 0.185 \\
\hline Bulgarian & 53.27 & 45.73 & 21.74 & 15.20 & 42.93 & 3.91 & 0.59 & 5.66 & 148.3 & 0.380 \\
\hline Australian & 2.47 & 40.63 & 47.69 & 11.68 & 71.66 & 5.42 & 1.57 & 2.86 & 179.5 & 0.370 \\
\hline
\end{tabular}

${ }^{\mathrm{a}}$ Volatile matter, ${ }^{\mathrm{b}}$ Fixed Carbon

Pyrolysis experiments were performed in a lab fixed bed reactor at ambient pressure, under helium flow at temperatures between 200 and $900^{\circ} \mathrm{C}$ and 5 to 120 min residence time. The pyrolysis prodedure and equipment is described in details elsewhere [5]. The obtained chars were characterized by standard methods. Proximate analysis was carried out using ASTM method D 3172-89. A ThermoFinnigan CHNS EA1112 elemental analyzer was used for the analysis of $\mathrm{C}, \mathrm{N}, \mathrm{H}$ and $\mathrm{S}$. Chlorine and mercury contents of the chars were determined by ASTM method D 4208-88 and EPA 7471A standard method, respectively. For the thermogravimetric tests, a TA Instruments TGA simultaneous DSC thermobalance (SDT Q600) was used. To avoid any interference in measurements accuracy, 20 $\mu \mathrm{g}$ of each char were loaded in an alumina crucible and placed on the thermobalance beam. Respal air with $20 \%$ oxygen content was applied for all the combustion tests. All samples were heated at the constant rate of $20^{\circ} \mathrm{C} / \mathrm{min}$ from ambient temperature to $1000^{\circ} \mathrm{C}$ with the constant air flow rate of $100 \mathrm{ml} \mathrm{min}^{-1}$. 


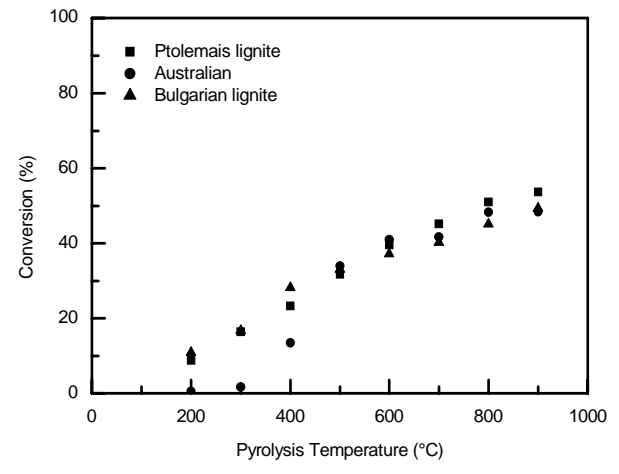

Figure 1. Effect of pyrolysis temperature on the conversion of the chars

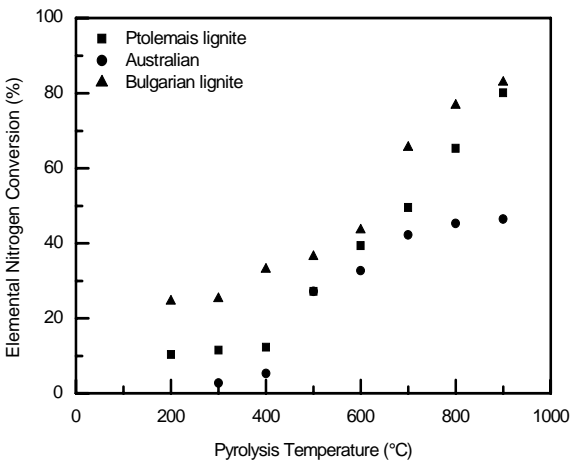

Figure 2. Effect of pyrolysis temperature on elemental nitrogen conversion of the chars

\section{RESULTS AND DISCUSSIOIN}

\subsection{Elemental conversion}

Figure 1 shows the effect of temperature on conversion of the chars. For all samples pyrolysis temperature increase results in higher conversion. For Ptolemais and Bulgarian coals an almost linear increase of conversion with temperature is observed, while for Australian coal a sigmoid shape is observed at low temperatures $\left(<450^{\circ} \mathrm{C}\right)$ and above this temperature seems to reach a plateau.

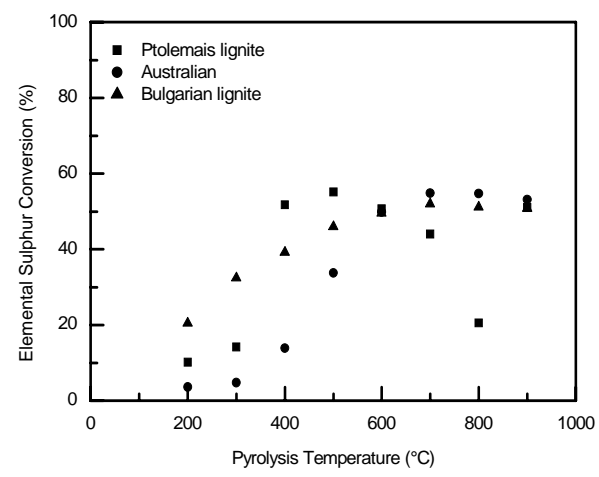

Figure 3. Effect of pyrolysis temperature on elemental sulphur conversion of the chars

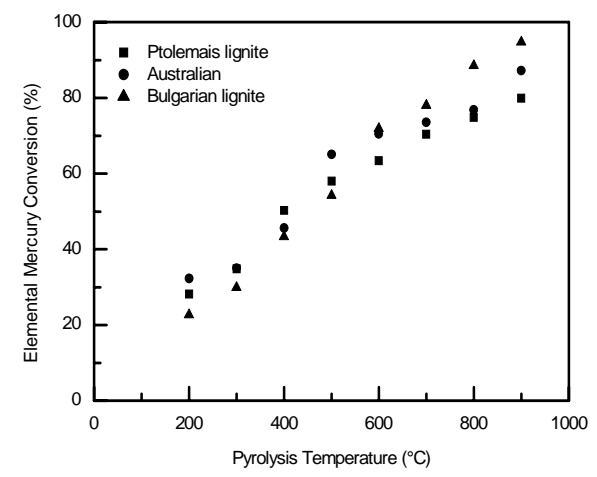

Figure 4. Effect of pyrolysis temperature on elemental mercury conversion of the chars

Indicative results for elemental nitrogen and sulphur conversion obtained are given in Figure $2-3$, respectively. At low temperatures nitrogen conversion is low (less than $10 \%$ ) and increases at higher temperatures. Between 500 and $600^{\circ} \mathrm{C}$, an amount of about $30-45 \%$ of the initial fuel nitrogen can be effectively removed by low temperature carbonization, and thus to reduce the risk of $\mathrm{NO}_{x}$ formation during coal combustion. At low pyrolysis temperatures sulphur conversion is low and increases as pyrolysis temperature increases. For Ptolemais lignite increases continuously up to $400^{\circ} \mathrm{C}$ and it seems that sulphur conversion reaches a plateau at about $450-550^{\circ} \mathrm{C}$. At higher temperatures discrepancies are observed, indicating possible reaction of sulphur with Ca present in high amounts in the Ptolemais lignite ash. The elemental sulphur conversion of the Bulgarian lignite and Australian coal sample increases continuously up to $600^{\circ} \mathrm{C}$ and reaches a plateau above this temperature. Pyrolysis seems to offer a viable solution in preventive removal of mercury and chlorine from solid fuels prior to its use in solid fuel combustion power plants. Some of the obtained results are given in Figure 5-6. 


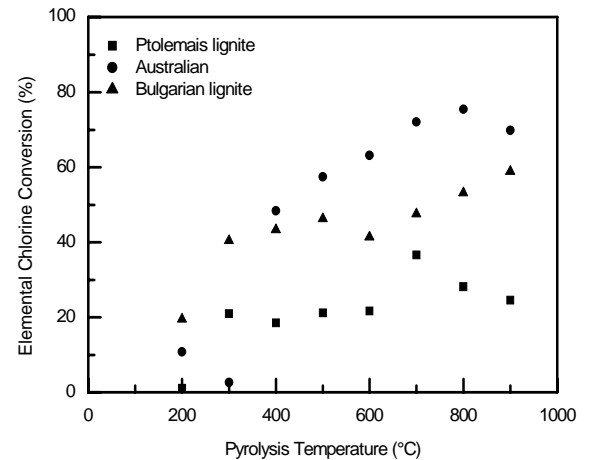

Figure 5. Effect of pyrolysis temperature on elemental chlorine conversion of the chars

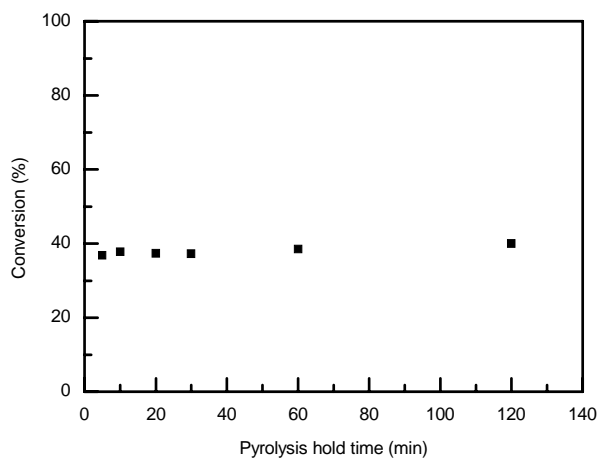

Figure 6. Effect of pyrolysis residence time on the conversion of Ptolemais lignite

Elemental mercury conversion increases almost linearly with pyrolysis temperature and very high conversions are achieved at high temperatures (up to $70 \%$ above $800^{\circ} \mathrm{C}$ ). About 40 to $50 \%$ and 55 to $65 \%$ of the initial elemental chlorine present in the Bulgarian lignite and Australian coal, respectively, is removed in the temperature region $400-700^{\circ} \mathrm{C}$. However, relatively limited chlorine conversion, $\sim 20$ to $30 \%$, was observed for Ptolemais lignite.

The effect of pyrolysis residence time was studied by performing tests with Ptolemais lignite at $600^{\circ} \mathrm{C}$ for various times (5-120 min). Weight loss is only slightly affected by the pyrolysis residence time due to the fact that fast pyrolysis reactions are completed in the first few minutes as shown from Figure 6 . In the same line volatiles and fixed carbon content are not actually affected by the prolongation of carbonisation time. The effect of carbonisation time does not affect the elemental conversion of the pollutants.

\subsection{Char oxidation}

Ptolemais lignite is the most important domestic energy source and possesses a special place in the Greek energy system since it is the main fuel for electricity production. For that reason the combustion behaviour of the partially pyrolysed chars originated by Ptolemais lignite was investigated by thermogravimetry.

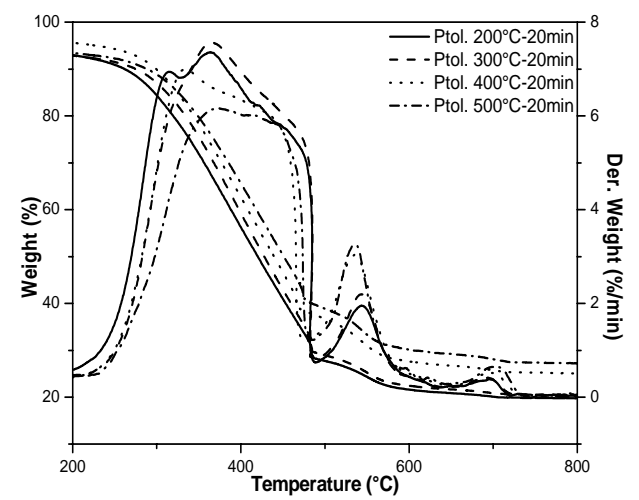

Figure 7. Weight loss and rate of weight loss as a function of temperature for the combustion of Ptolemais lignite chars prepared at $200-500^{\circ} \mathrm{C}$ for 20 minutes

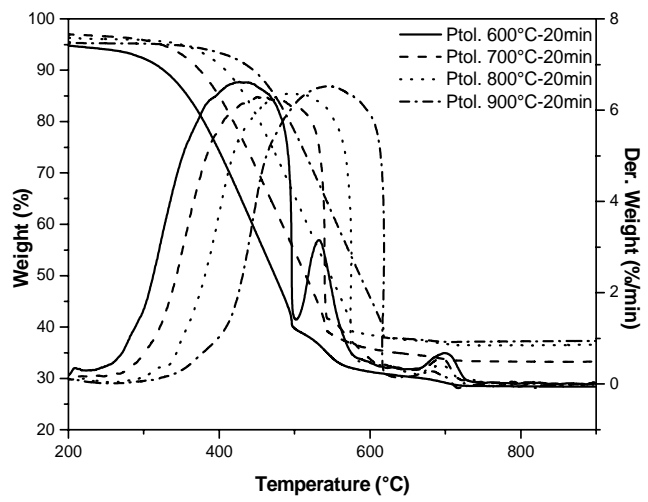

Figure 8. Weight loss and rate of weight loss as a function of temperature for the combustion of Ptolemais lignite chars prepared at $600-900^{\circ} \mathrm{C}$ for 20 minutes 
Char reactivity in oxygen atmosphere strongly affected by the pyrolysis conditions at which chars generated. It is well established that significant variations occurred between the DTG profiles of pure fuels and their chars $[6,7,8]$ with the former being more reactive than the partly burned chars. Because of the findings reported in these earlier studies chars from Ptolemais lignite were prepared from 200 to $900^{\circ} \mathrm{C}$ and examined under oxidative conditions for kinetic evaluation. The representative results for the specific Greek lignite are exhibited at Figures 8 and 9 . The Figures point out that increased pyrolysis temperatures resulted to lower conversions and increased temperatures at which the combustion occurred. The time temperature history of the pyrolysis have reported by many authors $[8,9,10]$ to have strong effect to the char reactivity. This finding agrees also well with the results of Sentorun et al [6] who attributed this increase at the higher concentrations of mineral matter of the chars due to the evolution of the volatile matter during the carbonization stage. It may also be noted that temperatures at which combustion of the chars started, increased with respect to the temperatures that partially pyrolysed samples were generated.

The latter provoked a decrease of total conversions as presented by the TG curves. Furthermore, as Figures 7 and 8 illustrate, for the combustion of Ptolemais chars produced until $600^{\circ} \mathrm{C}$ for 20 minutes a second peak were revealed between 500 to $600^{\circ} \mathrm{C}$. This peak was annihilated at the DTG profile of Ptolemais chars generated at 800 and $900^{\circ} \mathrm{C}$ for 20 minutes giving rise to a unique peak at the temperature region of $300-600^{\circ} \mathrm{C}$. In order to establish a verification of the reactivity the method used by Russell et al [11] was employed. According to this model the pre-exponential factor of the Arrhenius equation was used to characterize the reactivity of each sample. From the mathematical point of view char reactivity was defined as $\ln \left(A_{0}\right)$ which arise by the equation:

$$
\frac{\left(\frac{d W}{d t}\right)}{-W}=A_{0} \cdot e^{-E / R T}
$$

$A_{0}$ is the pre-exponential factor at $50 \%$ conversion and $E$ supposed to be constant $(130 \mathrm{KJ}$ $\mathrm{mol}^{-1}$ ) since Russel et al proved that varied round this value for an extended number of coals. $\mathrm{T}$ is the temperature in $\mathrm{K}$ and $\mathrm{R}$ is the Gas constant $\left(8.314 \mathrm{~J} \mathrm{~mol}^{-1} \mathrm{~K}^{-1}\right.$ ). Figure 9 points out the correlation between the reactivity and the presence such of fixed carbon as of volatiles in the generated chars. Increased reactivities were observed for chars with increased volatile and fixed carbon content. As above reported, it is already well known that pyrolysis temperature strongly affect in inversely proportional manner mainly the volatile content of the partly pyrolysed chars. These observations confirm the previously discussed reactivity decrease with respect to the char generation temperature.

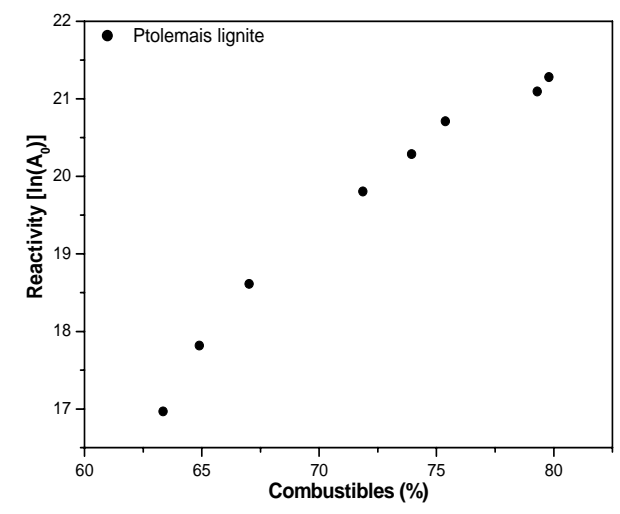

Figure 9. Reactivity of Ptolemais lignite as a function of combustibles (Fixed Carbon and Volatiles) concentration in chars

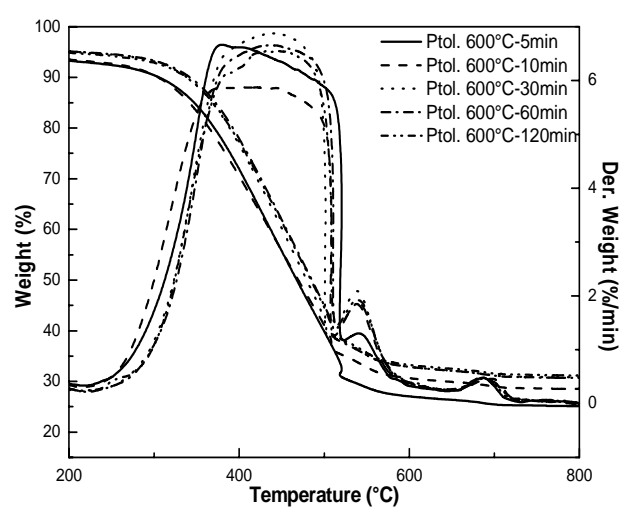

Figure 10. DTG curves as a function of temperature for the combustion of Ptolemais lignite chars prepared at $600^{\circ} \mathrm{C}$ for various times 
As already mentioned, pyrolysis time affect the characteristics of the produced chars. Figure 10 provides the TG / DTG curves obtained from the combustion of Ptolemais chars generated at constant temperature $\left(600^{\circ} \mathrm{C}\right)$ for various times ranged between 5 to 120 minutes. As it is clearly shown two main combustion behaviors could be ascribed. The first referred to the combustion of chars generated by the pyrolysis of Ptolemais lignite in short time intervals and the ones produced at higher pyrolysis times. In general, chars obtained at $600^{\circ} \mathrm{C}$ and lower pyrolysis times ( 5 and 10 minutes) appeared to be more reactive than partially pyrolysed char at elevated times. It may also be noted that the chars prepared at 5 and 10 minutes exhibited higher total conversions than the ones generated at higher pyrolysis times. The latter presented almost the same conversions. As figure 10 outlines three combustion stages could be distinguished. In the first and second stages chars presented the same combustion behaviour. At the third region DTG curves of all the chars coincided reflecting that combustion at about $700^{\circ} \mathrm{C}$ do not affected by the pyrolysis time variation. In essence, combustion time seems to have a little effect to the combustion behaviour of Ptolemais chars.

\section{CONCLUSIONS}

As a result, in this study it has been observed that sulphur, nitrogen, mercury and chlorine content was reduced during carbonization at $500-600^{\circ} \mathrm{C}$ for a residence time of $\sim 20 \mathrm{~min}$. Low temperature carbonization could be an effective way for clean coal production by removing a significant part of the existing polluting compounds in the coals and wastes without proper reduction of the reactivity. For that reason Ptolemais chars produced were investigated for air reactivity. The carbonization temperature affects the combustion reactivity of the generated chars. As pyrolysis temperature increased higher peak temperatures were observed reflection of the reduced reactivity of the chars. Pyrolysis time seems to have a slight effect on the char reactivity. Furthermore, the effect of carbonization time does not affect the elemental conversion of the pollutants. Thus, 20 min pyrolysis residence time is considered sufficient for effective removal of pollutants.

\section{REFERENCES}

1. Feng J., Li W.Y., Xie K-C., Liu M.R. and Li C.Z. (2003) Studies of the release rule of $\mathrm{NO}_{x}$ precursors during gasification of coal and its char, Fuel Proc.Tech., 84, 243-254

2. Merdes A., Keener T., Khang S.J. and Jenkins R. (1998) 'Investigation into the fate of mercury in bituminous coal during mild pyrolysis', Fuel, 77(15), 1783-1792

3. Puente G, Fuente E. and Pis J.J. (2000) Reactivity of pyrolysis chars related to precursor coal chemistry, J. Anal. Appl. Pyrolysis, 53, 81-93

4. Shaw K., Beamish B. and Rodgers K.A. (1997) Thermogravimetric analytical procedures for determining reactivities of chars from new Zealand coals, Thermochimica Acta, 302, 181-187

5. Zabaniotou A.A., Stauropoulos G. (2003), "Pyrolysis of used automobile tires and residual char utilization", J.Anal.Appl.Pyrolysis, 70, 711-722

6. Sentorun C., Haykiri-Acma H., Kucukbayrak S. (1996) Effect of mineral matter on the combustion curve of chars, Thermochimica Acta, 277, 65-73.

7. Haykiri-Acma H., Ersoy-Maricboyu A., Kucukbayrak S. (2001) Effect of mineral matter on the reactivity of lignite chars, Energy Conversion \& Management, 42, 11-20.

8. Alonso M.J.G., Borrego A.G., Alvarez D., Parra J.B., Menendez R., (2001) Influence of pyrolysis temperature on char optical texture and reactivity, J. Anal. Appl. Pyrolysis, 58-59, 887-909.

9. Di Blasi C., Buonanno F., Branca C., (1999) Reactivities of some biomass chars in air, Carbon, 37, 1227-1238.

10. Chen G., Yu Q., Sjostrom K. (1997) Reactivity of char from pyrolysis of birch wood, J Anal. Appl. Pyrolysis, 40-41, 491-499.

11. Russell N.V., Beelay T.J., Man C.K., Gibbins J.R., Williamson J. (1998) Development of TG measurements of intrinsic char combustion reactivity for industrial and research purposes, Fuel Processing Technology, 57, 113-130. 